\title{
PAIN CHARACTERISTICS OF TEMPOROMANDIBULAR DISORDER - A PILOT STUDY IN PATIENTS WITH CERVICAL SPINE DYSFUNCTION
}

\author{
CARACTERISTICAS DA DOR EM PORTADORES DE DISFUNÇÃO TEMPOROMANDIBULAR \\ - ESTUDO PILOTO EM PACIENTES COM DISFUNÇ̃̃O DA COLUNA CERVICAL
}

\author{
Cristiane Rodrigues PEDRONI ${ }^{1}$, Anamaria Siriani de OLIVEIRA ${ }^{2}$, Fausto BÉRZIN ${ }^{3}$
}

\begin{abstract}
1- PT, MSc, Departament of Morphology, Dentistry School of Piracicaba - State University of Campinas, Piracicaba, São Paulo, Brazil. 2- PT, MSc, PhD, Assistant Professor, Departament of Biomechanics, Medicine and Rehabilitation of Locomotor Apparatus, Ribeirão Preto School of Medicine, University of São Paulo, Ribeirão Preto, São Paulo, Brazil.

3- DDS, MSc, PhD, Head Professor, Departament of Morphology, Dentistry School of Piracicaba, State University of Campinas,Piracicaba, São Paulo, Brazil.
\end{abstract}

Corresponding address: Cristiane Rodrigues Pedroni - Rua Felício Gifini, 453, Jd. Nova Itália, Limeira, São Paulo - Cep.: 13.484-331

Received: December 12, 2005 - Modification: April 18, 2006 - Accepted: June 02, 2006

\begin{abstract}
0

bjective: The purpose of the present pilot study was to describe pain complaints of TMD patients and cervical spine dysfunction. Methods: Fourteen women with myogenous TMD, cervical motion limitation and rotation of at least one of the three first cervical vertebrae evidenced by radiographic examination participated in this study. The multidimensional pain evaluation was accomplished by a Brazilian version of the McGill Pain Questionnaire. Results: The results showed that the most painful body site mentioned was cervical spine, followed by scapular region and temporomandibular joint. More than half of the volunteers reported temporal pain pattern as rhythmic, periodic and, or still, intermittent. The majority of the patients classified the pain intensity assessed at the moment of the evaluation as mild to discomforting. Absolute agreement was not observed among volunteers regarding word dimensions used to describe their pain, although a great number of patients chose the descriptor related to tension as the better expression to describe their painful complaint. Conclusion: Pain characteristics of TMD patients with cervical spine dysfunction showed cervical spine as a common painful region reported and words related to affective and emotional dimensions of pain perception can be used by these patients to qualify their pain complain.

Uniterms: Temporomandibular disorder; Pain; McGill Questionnaire; Cervical spine.
\end{abstract}

\begin{abstract}
RESUMO
bjetivo: O objetivo deste trabalho foi descrever as queixas de dor em portadores de Disfunção Temporomandibular (DTM) com disfunção da coluna cervical. Métodos: Participaram desta pesquisa 14 portadores de DTM miogênica, do sexo feminino, com limitação do movimento cervical e rotação de pelo menos uma das três primeiras vértebras cervicais, diagnosticada através de exame radiográfico. A avaliação multidimensional da dor foi realizada usando uma versão brasileira do questionário McGill de dor (Br-MPQ). Resultados: Foi observado que a região mais indicada como dolorosa foi a região cervical, seguida pela região da cintura escapular e articulação temporomandibular. Com relação ao padrão temporal da dor, mais da metade dos voluntários anotaram que suas queixas tinham uma característica ritmada, periódica ou intermitente. A intensidade da dor presente registrada no momento da avaliação foi classificada como de leve a forte para a maior parte dos participantes da pesquisa. Nenhuma das dimensões de palavras que descrevem a dor obteve concordância absoluta entre os voluntários, porém a maioria dos voluntários escolheu o descritor relacionado à tensão como a expressão que melhor descreve sua queixa dolorosa. Conclusão: A característica da queixa de dor, dos portadores de DTM e disfunção da coluna cervical, mostrou que a região cervical é a área mais freqüentemente indicada e que palavras relacionadas as dimensões afetiva e emocional, da percepção de dor, podem ser usadas por estes pacientes para qualificar sua queixa de dor. Unitermos: Disfunção temporomandibular; Dor; Questionário McGill; Coluna cervical.
\end{abstract}




\section{INTRODUCTION}

Today it is known that Temporomandibular Disorder (TMD) etiology is multifactorial. It may be related to an imbalance among occlusal, anatomical, psychological and neuromuscular factors, promoting neck and head structural dysfunction ${ }^{1}$. A great number of studies have been focused on the biomechanical and neuroanatomical interactions between stomatognathic and cervical systems, whereas masticatory pain symptoms may be generated by cervical spine disorders ${ }^{1-8}$.

The McGill pain questionnaire (MPQ) is an instrument that allows evaluation of multidimensional aspects of pain features such as temporal pattern, localization and intensity, and is designed with qualitative and quantitative descriptors to assess sensorial, affective, subjective and mixed pain dimensions. This questionnaire has been shown to be effective in studies involving TMD patients ${ }^{8-10}$, but it has been minimally applied in Brazilian population studies. Oliveira et al. ${ }^{11}$, using a Brazilian version of the McGill Pain Questionnaire (Br-MPQ) ${ }^{12}$, evaluated 23 TMD patients previously classified by application of the severity clinical index and reported that severe TMD patients indicated the TMJ as the main area of pain, while moderate TMD patients reported the cervical spine as main painful area. The study above was not carried out including exams to determine the presence of cervical spine alterations. However, postural alterations, as forward head posture and cervical curvature rectification, have been found in TMD patients ${ }^{13}$.

Moreover, TMD patients report cervical pain more frequently than non-patients ${ }^{1,6}$. There is no agreement concerning the prevalence and the type of cervical spine disorder that could be related to TMJ pain. Because of this interaction neck and head postural alterations, vertebra's misalignment or injuries in these regions could lead to motor control dysfunction in these regions, and mandible functional impairment and pain.

Since it cannot be considered as a local disorder, the inspection and evaluation of cervical spine is recommended as a part of TMD patient's physical examination ${ }^{6,7}$. However, there is no study describing the multidimensional characteristics to pain complaint in TMD patients that have a cervical dysfunction. Considering such interaction between stomatognathic and cervical systems, the purpose of the present pilot study was to describe pain complaints of TMD patients with a proved cervical dysfunction, vertebral rotation and movement limitation, using $\mathrm{Br}-\mathrm{MPQ}$ proposed by Castro ${ }^{12}$.

\section{MATERIALAND METHODS}

\section{Volunteers}

The Institutional Ethics Committee gave scientific and ethical approval without restrictions and the subjects' written informed consent was obtained, after explanation of the general nature of this study. Because women are most commonly affect by $\mathrm{TMD}^{14}$ and they look for treatment more than men ${ }^{15}$, they were chose to participate in this study. Sixteen women with myogenous TMD were referred by dentists from a school clinic to participate in this study.

The volunteers reported chronic masticatory muscle pain during functional activation, occlusal parafunction (sleep bruxism or teeth clenching habit), pain, stiffness or fatigue at wake-up. Patients with dental absences, systemic or general joint disease that could affect TMJ or cervical joints such as rheumatoid arthritis, osteoarthrosis, osteoporosis, diabetes, primary headaches and who had been taking analgesic, muscle relaxants or anti-inflammatory drugs were excluded. All patients must have had movement limitation and rotation of at least one of the first three cervical vertebrae, evidenced by radiographic assessment to be included into this study.

The reduction of 5 degrees or more than this in at least 1 of the cervical motions was considered range of motion limitation. After proving the movement limitation by fleximeter assessment of cervical spine motions ${ }^{16,17}$, all volunteers were asked to undergo radiographic examination to confirm the cervical spine vertebral rotation. One transoral radiographic image was took by calibrated G.E. 1000 x-ray generator at $68 \mathrm{kVp}, 10 \mathrm{~mA}$ and 21 impulses exposure time, using an image intensifier. The target-film-distance was 70 $\mathrm{cm}$, and the central beam passed through the oral commissure. To perform the radiographic exam the patient must be seated, with a maximal open mouth, posterior head region placed against the chassis, which was fixed at the wall by a support, and be in $10^{\circ}$ of head extension related to Frankfurt plane. The misalignment of spinous process considering the medial line passing through the middle of the cranium was accepted as vertebral rotation. ${ }^{18}$ Recommendations from International Commission on Radiological Protection (ICRP) and National Commission of Nuclear Energy (CNEN) were followed, regarding patient, operator, environment and control of image quality.

All the volunteers filled the anamnestic questionnaire ${ }^{19}$ and were assessed by an expert experimenter. The clinical examination consisted of inspection, palpation, evaluation of mandibular mobility and joint sound auscultation ${ }^{14,20}$. The presence of trigger points in the masticatory muscles, head, cervical region and scapular girdle musculature was evaluated by performing a moderate digital pressure on the points ${ }^{14,20}$. Palpation of the masticatory musculature was performed on the temporal and masseter muscle belly. The medial pterygoid muscle was palpated intraorally ${ }^{14,20}$.

Fourteen women with myogenous TMD, chronic pain according IASP ${ }^{21}$ classification and cervical spine dysfunction, age 19 to 40 years (mean $23.3+8.7$ years old), were selected to participate in this pilot study. They had severe $(75 \%)$ or moderated (25\%) symptoms of TMD, according to Fonseca's ${ }^{19}$ anamnestic questionnaire.

\section{Proceedings}

Instructions on how to complete the Br-MPQ were given to the patients who then completed the questionnaire. Each participant had to indicate all painful body sites on the $\mathrm{Br}$ MPQ drawing ${ }^{11,12,22}$ and choose the best words to express 
their pain experience related to TMD. These words were distributed in 20 items such as sensory dimension (10), affective (5), evaluative (1) and mixed words (4). Only one word could be selected from each item and it was not necessary choosing words from all items. The questionnaire allowed classifying temporal pain pattern and pain intensity during the evaluation session. Data obtained from Br-MPQ ${ }^{12}$ included information about pain localization, temporal pain pattern, present pain intensity (Present Pain Index - PPI) and the pondered pain (Pain Rate Index - PRI). Descriptor subclass and the words chosen by the subjects were also presented. The results were analyzed using a descriptive analysis of data frequency distribution.

\section{RESULTS}

The most frequently reported pain area indicated by TMD patients with cervical vertebral rotation was the cervical spine (92.85\%), followed by the scapular region (50\%). TMJ was the third most commonly indicated site (42.85\%) while the masseter muscle was the main masticatory muscle considered as a painful area (35.71\%). The temporal muscle (21.42\%) and frontal region (28.57\%) were pain areas also indicated by TMD patients.

More than half (57.14\%) of the participants characterized the pain as rhythmic, periodic or intermittent; while $35.71 \%$ characterized it as continuous, stable or constant. The least frequently reported pattern was brief, momentary or transitory pain $(7.14 \%)$.

Some of the subjects classified their pain intensity at the evaluation moment as mild (35.5\%) or distressing (21.42\%). The majority of volunteers classified their pain as discomforting (42.85\%) and no subjects reported no pain nor identified their pain as horrible or excruciating during the evaluation.

The scale pain index - the pondered PRI (Table 1) was calculated by summing the weighted item scores within each subscale and dividing each sum by the number of items in that subscale. Using this method, the score "zero" demonstrated that nobody chose that dimension and the score "one" indicated that everybody chose the maximum word score in each possible dimension item. The observed values represent the relative contribution of each of the perceived pain dimensions in the global composition of the perceived pain, whereas each dimension has a number of subclasses and different descriptors.

The descriptive dimension words selected are presented in Table 2. The median values show that the affective dimension was the most important contributor to the pain description. Nevertheless, there was considerable variation among the extreme scores obtained from the questionnaire. The words preferred by TMD patients with cervical vertebral rotation are presented in Table 2 . The results showed that the "displeasure" subclass (affective pain dimension) was the most commonly chosen subclass among volunteers of this study, followed by "emotional" (mixed words dimension), "constrictive pressure" and "general” (both from sensory dimension). Table 2 illustrated the most commonly selected word subclasses and the descriptors most commonly reported. In the mixed words dimension, emotional subclass, "that leaves me nervous" was pointed out by $71.43 \%$ as the descriptors that expressed their pain.

\section{DISCUSSION}

The results obtained from the Br-MPQ human body diagram demonstrated a great prevalence of cervical pain reported by volunteers of this study. This result is not in agreement with early report ${ }^{23}$ that pointed the TMJ as the most common area of pain in TMD patients. Using the Fonseca's anamnestic questionnaire to evaluate Brazilian TMD patients, Oliveira et al. ${ }^{11}$ found that the majority of severe TMD patients mentioned TMJ as the main symptomatic region, while moderate TMD patients indicated the cervical region more frequently. However, no clinical or radiographic examination was carried out to confirm the evidence of cervical spine functional and/or structural alterations in the volunteers of the mentioned study.

Patients with TMD are subject to neck pain, functional limitation and tenderness in the cervical spine, more frequently than normal control groups ${ }^{2,24-26}$. Various authors point to the need of evaluation and treatment of cervical spine $^{4,13,27-29}$. However, there is no consensus on the frequency and type of cervical disturbance that can cause pain in the TMJ. In the present study, the association of movement limitation and rotation of at least one of the first three cervical vertebrae were considered indicative of cervical dysfunction as proposed by Pacciani, et al. ${ }^{30}$ The results of the present study suggest that there is a difference in main pain localization to TMD patients who have cervical dysfunction from those who have just TMD diagnosis. However, multidimensional pain evaluation in a TMD "noncervical dysfunction” control group is necessary to confirm this suspicion.

The temporal pain pattern showed that the majority of the subjects described their pain as rhythmic, periodic or

TABLE 1- Pondered median values from the pain index evaluation in scale (PRI) related to sensory, affective, evaluative, mixed words dimensions and the total score. Minimum and maximum values are demonstrated in parentheses. $(n=14)$

\begin{tabular}{ccccc}
\hline Sensory & Affective & Evaluative & Mixed & Total \\
\hline 0.21 & 0.38 & 0.35 & 0.23 & 0.27 \\
$(0.03-0.59)$ & $(0.06-0.88)$ & $(0-1.00)$ & $(0.08-0.58)$ & $(0.10-0.67)$ \\
\hline
\end{tabular}


intermittent, suggesting the perception of intervals between painful events by the patients, a common characteristic of mechanical pain. The TMD patients who indicate the cervical as an important painful area and reported that their symptoms worsen according to the spine movement must be referred to an orthopedic physician or to a physical therapist ${ }^{6}$. Presence of mechanical pain related to the cervical spine suggests that well conducted anamnesis and physical examination could be important to plan a multiprofessional care to the patient's condition ${ }^{6,11}$.

The PPI values at the moment of the evaluation demonstrated that all patients have presented with some pain, which was described from mild to annoying. In general, patients that have chronic pain, like those assessed in this study, demonstrated bigger attention to painful region, depression and resignation behaviors ${ }^{31}$. Such behaviors could result in lower pain intensity reports when comparing patients with chronic and acute pain ${ }^{31}$.

The median pondered values of the PRI in each of the pain dimensions chosen showed more contribution of the affective dimension to the qualitative pain description. In this way, it is possible to suggest an association of pain unpleasantness (affective dimension) to the perception and memory of pain ${ }^{11}$.

Emotional stress has been mentioned in many studies as characteristic of TMD patients ${ }^{14,32,33}$. This emotional stress became evident during the analysis of the subclass and descriptor of pain chosen by the subjects. The most frequently chosen subscales were "displeasure” (affective dimension) and the descriptor "that leaves me nervous" (emotional subscale) demonstrating the influence of affective and emotional dimensions upon the painful symptoms perception of TMD patients with cervical dysfunction.

The Brazilian version of Br-MPQ was important to identify multidimensional aspects of pain complain in TMD patients that have cervical dysfunction. However, more studies must be conducted comparing the characteristics of pain to these of the TMD "non-cervical dysfunction" control group.

\section{CONCLUSION}

Pain characteristics of TMD patients with cervical spine dysfunction, assessed by the McGill pain questionnaire (Brazilian version), showed the cervical spine as a common painful region reported by the subjects. Words related to affective and emotional dimensions of pain perception can be used by these patients to qualify their pain complaints. Other studies must be carried out using the Br-McGill questionnaire for a better understanding of the pain related to TMD and cervical dysfunction.

TABLE 2- Frequency of the most reported subclasses and descriptors in each one of the qualitative dimensions of TMD patient's pain $(n=14)$

\begin{tabular}{|c|c|c|}
\hline Dimension & Subclass & Descriptor \\
\hline \multirow[t]{6}{*}{ SENSORIAL } & Constrictive Pressure & pressing \\
\hline & $(64.28 \%)$ & $(50.0 \%)$ \\
\hline & General & weighting \\
\hline & $(64.28 \%)$ & $(35.71 \%)$ \\
\hline & Temporal & pulsing \\
\hline & $(57.14 \%)$ & $(28.57 \%)$ \\
\hline \multirow[t]{6}{*}{ AFFECTIVE } & Displeasure & annoying \\
\hline & $(92.85 \%)$ & $(28.57 \%)$ \\
\hline & & "that makes me cry" \\
\hline & & $(28.57 \%)$ \\
\hline & Fatigue & tiring \\
\hline & $(50.00)$ & $(21.43 \%)$ \\
\hline \multirow[t]{2}{*}{ EVALUATTIVE } & Subject Evaluation & discomfort \\
\hline & $(21.43 \%)$ & $(28.57 \%)$ \\
\hline \multirow[t]{2}{*}{ MIXED } & Emotional & "that leaves me nervous" \\
\hline & $(85.71 \%)$ & $(71.43 \%)$ \\
\hline
\end{tabular}




\section{ACKNOWLEDGEMENTS}

This study was supported by Fundação de Amparo à Pesquisa do Estado de São Paulo - FAPESP (process number 01/04253-3).

\section{REFERENCES}

1- Clark GT, Green EM, Dornan MR, Flack VF. Craniocervical dysfunction levels in a patient sample from a temporomandibular joint clinic. J Am Dent Assoc. 1987;115:251-6.

2. Aprill C, Dwyer A, Bogduk N. Cervical zygapophyseal joint pain patterns II: A clinical evaluation. Spine. 1990;15:458-61.

3- Dreyfuss P, Michaelsen M, Fletcher D. Atlanto-occipital and lateral atlanto-axial joint pain patterns. Spine. 1994;15:1125-31.

4- Kiveskari P, Alanen P, Karskela V, Kaitaniemi P, Holtari M, Virtanen $\mathrm{T}$, et al. Association of functional state of stomatognathic system with mobility of cervical spine and neck muscle tenderness. Acta Odontol Scand. 1998;46:281-6.

5- Star MJ, Curd JG, Thorne RP. Atlanto-axial lateral mass osteoarthrits: A frequently overlooked cause of severe occipitocervical pain. Spine. 1992;17:71-6.

6- Steenks MH, De Wijer A. Disfunções da articulação temporomandibular do ponto de vista da fisioterapia e da odontologia. São Paulo: Ed. Santos; 1996.

7- Zafar H. Integrated jaw and neck function in man: studies of mandibular and head-neck movements during jaw opening-closing tasks. Swed Dent J. 2000;143:1-41.

8- Campbell LC, Riley JL, Kashikar-Zuck S, Gremillion H, Robinson ME. Somatic, affective, and pain characteristics of chronic TMD patients with sexual versus physical abuse histories. J Orofac Pain. 2000;14:112-9.

9- Mongini F, Italiano M. TMJ disorders and myogenic facial pain: a discriminative analysis using the McGill pain questionnaire. Pain 2001;91:323-30.

10- Mongini F, Italiano M, Raviola F, Mossolov A. The McGill pain questionnaire in patients with TMJ pain and with facial pain as a somatoform disorder. Cranio. 2000;18:249-56.

11- Oliveira AS, Bermudez CC, Souza RA, Freitas CMS, Castro CES, Bérzin F. Avaliação multidimensional da dor em portadores de desordem temporomandibular utilizando uma versão brasileira do Questionário McGill de Dor. Rev Bras Fisioter. 2003;7:151-8.

12- Castro CES. A formulação lingüística da dor - versão brasileira do questionário McGill de dor São Carlos; 1999. [Dissertação (Mestrado) - Universidade Federal de São Carlos].

13- De Wijer A. Distúrbios temporomandibulares e da região cervical. São Paulo: Ed. Santos; 1998.

14- Pedroni CR, Oliveira AS, Guaratini MI. Prevalence study of signs and symptoms of temporomandibular disorders in university students. J Oral Rehabil. 2003;30:283-9.

15- MagnussonT, Egermark I, Carlsson GE. A longitudinal epidemiologic study of signs and symptoms of temporomandibular disorders from 15 to 35 years of age. J Orofac Pain. 2000;14:310-9.

16- Norderman R, Thorner C. Treatment of acute cervical pain: A comparative group study. Pain. 1981;10:93-101.
17- Farah EA, Tanaka C. Postura e mobilidade da coluna cervical e do tronco em portadores de alterações miofuncionais orais. Rev Assoc Paul Cir Dent. 1997;51:171-4.

18- Richardson JK, Iglarsh AZ. Clinical orthopaedic physical therapy. United States: Ed. Saunders; 1994.

19- Fonseca DM. Disfunção craniomandibular (DCM): elaboração de um índice anamnésico. Bauru; 1992. [Dissertação (Mestrado) Faculdade de Odontologia de Bauru da USP].

20- Dworkin SF, LeRescheL. Research diagnostic criteria for temporomandibular disorders: review, criteria, examinations and specifications, critique. J Craniomandib Disord. 1992;4:301-55.

21- IASP. Classification of chronic pain: descriptors of chronic pain syndromes and definitions of pain terms. 2nd ed. Seatle: IASP Press; 1994.

22- Oliveira AS. Evaluation of quality of life and pain in temporomandibular disorders (TMD). Braz J Oral Sci. 2005;4:64650 .

23- Dibbets JM, Van Der Weele LT. Extraction, orthodontic treatment, and craniomandibular dysfunction. Am J Orthod Dentofacial Orthop. 1991;99: 210-9.

24- Alanen PJ, Kiverskari PK. Ocupational cervicobrachial disorder and temporomandibular joint dysfunction. Cranio. 1984;3:69-72.

25- Cacchiotti DA, Plesh O, Bianchi P, McNeill C. Signs and symptoms in samples with and without temporomandibular disorders. J Craniomandib Disord. 1991;3:167-72.

26- De Laat A, Meuleman H, Stevens A. Relation between functional limitations of the cervical spine and temporomandibular disorders [abstract]. J Orofacial Pain. 1993;1:109.

27- Fuentes R, Freesmeyer W, Henriquez J. Influencia de la postura corporal en la prevalência de las disfunciones craneomandibulares. Rev Med Chil. 1999;127:1079-85.

28- Janda V. Some aspects of extracranial causes of facial pain. J Prosthetic Dent. 1986;4:484-7.

29- Rocabado M, Johnston BE, Blakney MG. Physical therapy and dentistry: An overview. J Craniomandibular Pract. 1982;1:46-9.

30- Pacciani E, Salsano ML, Donnetti L, Urso S. Clinico-radiologic correlations in common neck pain. Radiol Med. 1996;91:570-6.

31- Wells-Federman C, Arnstein P, Caudill M. Nurse-led pain management program: Effect on self-efficacy, pain intensity, painrelated disability, and depressive symptoms in chronic pain patients. Pain Manag Nurs. 2002;3:131-40.

32- Kampe T, Tagdae T, Bader G, Edman G, Karlsson S. Reported symptoms and clinical findings in a group of subjects with longstanding bruxing behaviour. J Oral Rehabil. 1997;24:581-7.

33- Oakley ME, McCreary CP, Flack VF, Clark GT, Solberg WK, Pullinger AG. Dentists' ability to detect psychological problems in patients with temporomandibular disorders and chronic pain. J Am Dent Assoc. 1989;118:727-30. 